\title{
Acetylcholinesterase Activity in Nile Tilapia (Oreochromis niloticus Linn.) Following Exposure to Carbamate Insecticide
}

\author{
Ris Menoel R. Modina *
}

\begin{abstract}
Acetylcholinesterase (AChE) activities were determined as affected by exposure to sublethal doses of fenobucarb (BPMC) on Nile tilapia. Fish were exposed for different periods, namely: $0,7,14,21$, and 28 days. AChE activities of brain and muscle tissues were measured spectrophotometrically. The sublethal doses of the insecticide did not induce treatment-related poisoning but were enough to significantly induce effects on the hepatosomatic index. The concentration used was also enough to significantly induce AChE inhibition on brain and muscle. AChE inhibitions were significantly different between unexposed and exposed fish in both brain $(K W=14.02, P<0.05)$ and muscle $(\mathrm{KW}=6.87, \mathrm{P}<0.05)$ tissues. The inhibition on brain AChE was highest on the 14 day-exposed fish. The inhibition on muscle AChE was highest on the 21-dayexposed fish which could be due to the direct exposure of muscle tissues to toxicants. The sensitivity of the relative liver weights and AChE activity of Nile tilapia could therefore be used as potential bioindicator of carbamate insecticide contaminated waters.
\end{abstract}

Keywords: fenobucarb (BPMC), acetylcholinesterase (AChE) inhibition, bioindicator, Nile tilapia, Oreochromis niloticus Linn.

\section{INTRODUCTION}

Pesticides are agents that are synthetically produced to rid humans of anything considered as "pests" such as mosquitoes, midge larva, pests of various agricultural crops, undesirable fishes, aquatic weeds, and aquatic snails (Que Hee 1993, Aragon 2000). Synthetic pesticides are well known as a cost-effective method of pest control, but these chemicals are toxic to aquatic species, particularly fish. The indiscriminate use of such chemicals is a growing concern worldwide which results in environmental pollution and toxicity risk to nontargeted organisms (Coppage \& Bradeich 1976, Venkateswara Rao 2004).

Department of Biological Sciences, Visayas State University, Visca, Baybay City, Leyte 6521-A Philippines

*Corresponding Author. Address: Department of Biological Sciences, Visayas State University, Visca, Baybay City, Leyte 6521-A Philippines. E-mail: rismenoel.modina@vsu.edu.ph Tel No. (053) 335-7536 DOI: $10.32945 /$ atr3927.2017 
In the Philippines, the use of pesticides is an essential part of crop production, especially vegetables and rice, which increases crop yields by $28 \%$. Insecticides are the most commonly used pesticide in the Philippines and represent $39 \%$ of the Php 6 billion pesticide market for 2005 (Rondon 2005).

Presently, organophosphorus pesticides (Ops), carbamates, pyrethoids, and triazines have largely replaced the organochlorine compounds in agricultural practices. They have the advantage of being less persistent in the environment (Varo et al 2000). Although they have such advantage, Gruber and Munn (1998) suggested that these substances could still affect non-target aquatic biota since they are applied for extended periods of the year, especially during growing season, when most usage occurs.

In determining chemical characteristics of pollutants and their concentrations, organisms and their biomolecules represent a useful choice as biomarkers, since they employ both the chemical and the biological approaches in environmental biomonitoring. Moreover, they also allow estimation of the impact of these pollutants to such species that provide the target molecules (Wijesuriya \& Rechnitz 1993, Watson \& Mutti 2004). Among these compounds, enzymes play an important role due to their degree of specificity and fast response to relevant changes in the surrounding medium. The use of enzymes as bioindicators is based on the inhibition or negative interference in catalytic activity triggered by analytes (Marco \& Barceló 1996). Cholinesterase inhibition has been used as biomarker of carbamate exposure. AChE is one of the oldest environmental biomarkers (Payne et al 1996).

This study focused on carbamate, a cholinesterase inhibitor. It acts by carbamoylating the serine residue at the active site of the ChEs. Their structures present either similarities to the substrates or their hydrolytic intermediates and interact very slowly with the enzyme by forming stable conjugates (Tõugu 2001). This mechanism hinders the normal functioning of the enzyme, which cannot prevent the accumulation of the neurotransmitter in the synaptic cleft. The overstimulation caused by acetylcholine continuously firing its receptors generates a range of signs and symptoms. Because of their low environmental persistence and high toxicity, particularly to aquatic organisms, water must be continuously monitored (Beauvais et al 2002).

Carbamate pesticides are presently used in the Philippines, particularly in farms around Laguna de Bay (Calumpang et al 1997, Varca 2012) which could find its way to the lake and could have detrimental effects on non-target species. The findings of this study would provide a tool for evaluating the efficiency of using AChE activity in the central nervous system (brain) and peripheral NS (skeletal muscle) as potential biomarkers for the presence of carbamate pesticides in freshwater ecosystems such as rivers and lakes.

\section{MATERIALS AND METHODS}

\section{Procurement and Selection of Tilapia Samples}

A total of 50 fry of Nile Tilapia (Oreochromis niloticus L.) was used in this study. The test animals were obtained from the Demonstration Farm of the Bureau of Fisheries and Aquatic Resources (BFAR) in Bay, Laguna. The fish averaged $3 \mathrm{~cm}$ in length and $7 \mathrm{~g}$ in weight. From the farm, they were brought to the laboratory 
Acetylcholinesterase Activity in Nile Tilapia

inside plastic bags half-filled with water and adequately provided with oxygen. The fishes were then transferred to a $40-$ liter $(25 \times 50 \times 30 \mathrm{~cm})$ aquarium filled with 35 liters of aged tap water. The tanks were fully aerated using a compressor. The fishes were allowed to acclimate for two weeks and were given fish commercial starter crumble pellets regularly. Water in the aquaria was changed daily.

\section{Description of Test Chemical}

The carbamate insecticide used was fenobucarb or BPMC (Hopcin $\AA)$. Hopcin $50 \mathrm{EC}$ (Wuhan Chemwish Technology Company) is a formulation with $500 \mathrm{~g} \mathrm{BPMC/}$ $\mathrm{kg}$. This test material was chosen among a number of insecticides because this pesticide is being used in rice fields and farms in Lumban and Pangsanjan, Laguna and was detected in waters of Laguna de Bay and tributary rivers (Bajet et al 2012, Varca 2012).

\section{Time-course pattern experiment}

All 50 fishes were randomly distributed into $25 \times 50 \times 30 \mathrm{~cm}$ tanks (labeled A to E) filled with $40 \mathrm{~L}$ aged tap water. The test concentration of BPMC used was $0.08 \mathrm{mg} / \mathrm{L}$. This concentration was reported by Calumpang et al (1997) as the detectable amount of residues of BPMC in irrigation areas. At the start of the experiment, all the fish, except those in Tank $A$, were exposed to the treatment dose. Fish in Tank A served as the control and were sacrificed at the start of the treatment. The remaining fish were sacrificed at the end of the $7^{\text {th }}, 14^{\text {th }}, 21^{\text {st }}$ and $28^{\text {th }}$ day exposure periods. Brain and muscle samples were obtained for AChE evaluation. The number of dead test fish and any abnormalities in gross morphology and/or behavior, which may be due to insecticide exposure, were also noted. The general management and feeding of the fish were the same as already described above during the acclimatization period. Tanks were cleaned and replaced with new aged tap water daily, and fresh doses were provided.

\section{Post-mortem Analysis}

Test fishes were sacrificed at the end of every exposure period by decapitation. Individual fish were weighed using a top loading balance and were dissected. The liver and spleen were excised and weighed. Using the following formula, the relative organ weight (ROW) of each organ was calculated:

$$
\text { ROW }=\frac{\text { Absolute organ weight }(\mathrm{g})}{\text { Body weight of fish on the day of sacrifice }(\mathrm{g})} \times 100
$$

Brain and muscle samples were obtained to be used for AChE activity evaluation.

\section{Evaluation for AChEActivity}

AChE activities of the brain and muscle samples were determined spectrophotometrically following the procedure described by Ellman et al (1961). A 
20-mg tissue sample of muscle and brain was mixed with $1 \mathrm{~mL}$ of phosphate buffer $(\mathrm{pH} 8,0.1)$ and homogenized using a homogenizer. $\mathrm{A} 0.4 \mathrm{~mL}$ aliquot of the homogenate was added to a cuvette containing $2.6 \mathrm{~mL}$ of $0.1 \mathrm{M}$ phosphate buffer (pH 8). $100 \mu$ l of dithio-bis-nitrobenzoic acid (DTNB) was then added to the photocell. The mixture was mixed by bubbling for about 30 seconds and absorbance was measured at $412 \mathrm{~nm}$ every minute for a period of six minutes. A 20 $\mu \mathrm{L}$ of acetylthiocholine iodide $(0.075 \mathrm{M})$ was then added to the initial mixture, and absorbance was again measured for another six minutes. Changes in absorbance were recorded and the change per minute was calculated. The rates were calculated as follows:

$$
\mathrm{R}=5.74\left(10^{-4}\right) \times \frac{\Delta \mathrm{A}}{\mathrm{C} \circ}
$$

Where: $R=$ rate, in moles substrate hydrolyzed per minute per gram of tissue;

$\Delta \mathrm{A}$ = change in absorbance per minute;

$\mathrm{Co}=$ original concentration of tissue $(\mathrm{mg} / \mathrm{ml})$

Inhibition rates were computed using the following formula:

$$
\text { Inhibition rate }=\frac{\mathrm{R}(\text { control fish })-\mathrm{R}(\text { treated fish })}{\mathrm{R}(\text { control fish })} \times 100
$$

\section{Statistical Analysis}

Statistical analysis was carried out using Statistical Package for Social Sciences (SPSS 16.0 for Windows). Differences in relative organ weights, and AChE activities of the brain and muscle tissues among test groups were analyzed using the Kruskall-Wallis H Test Analysis of Variance.

\section{RESULTS AND DISCUSSION}

\section{Treatment-related Symptoms of Toxicity}

There were no treatment-related symptoms observed among individuals. This may be due to the very low concentration level of BPMC. Nile tilapia has an $\mathrm{LC}_{50}$ value of $9 \mathrm{mg} / \mathrm{L}$ for BPMC exposure as reported by De Silva and Ranasinghe (1989) which is -112 higher than the concentration used in this study $(0.08 \mathrm{mg} / \mathrm{L})$. This suggests that the concentrations used in this study were not enough to induce symptoms of toxicity.

Although there were no treatment-related symptoms observed among individuals, there were still minimal mortalities observed. Mortalities were observed in both treated and control group. This may be due to the presence of dominant and subordinate fish in the tanks. Evans et al (2008) observed behavior such as biting, ramming, and mouth-fighting among tilapia raised in aquaria. 
These behaviors were also observed among the fishes in the tanks in this study. These behaviors lead to stress or trauma on the subordinate fish, which resulted in breaks in the fins or scales (Figure 1). Scales and skin function as a physical barrier that protects the fish against injury. When these are damaged, a window for both biotic and chemical toxins starts to invade the system of the fish. Breaks in fins left the fish unable to swim and were incapable of moving towards the food. The subordinate fish that were traumatized by these aggressive behaviors eventually died.

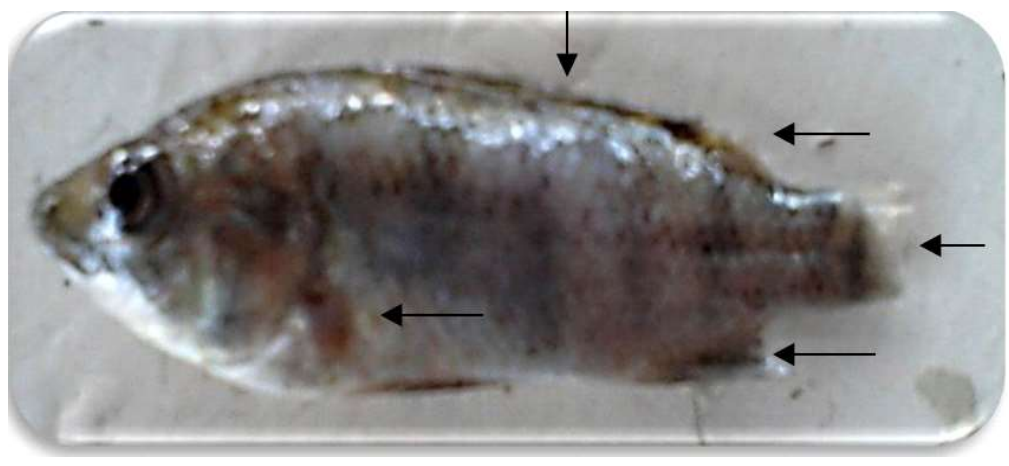

Figure 1. Subordinate fish suffered breaks in the fins (black arrows) due to presence of a dominant fish in tanks.

\section{Influence of Test Pesticide on Relative Organ Weights}

Figure 2 shows the relative mean weights of liver of Nile tilapia exposed to BPMC at different lengths of exposure. Analysis shows significant difference of relative weights of the fish $(\mathrm{KW}=21.88, \mathrm{P}<0.05)$. There is a decreasing trend of relative weights of the liver observed from 0 -days exposure until 14-day exposure and increased afterwards. This decrease in relative liver weights were also observed by Monteiro et al (2006), Chung et al (2002) and Gawish et al (2011) as a response to pesticide poisoning. This decrease in relative liver weights could have been the result of depletion of protein fraction as observed by Bose et al (2011), Tripathi et al (2003) and Singh et al (1996) on fish exposed to pesticides. The higher relative liver weights of 21- and 28-day exposed fish may have been an adaptive process and also suggests recovery as stated by Bose et al (2011). There were no definite patterns observed in the relative weights of the spleen. This could suggest that the test pesticides did not induce effects on the spleen but histological analysis could be recommended to further test the effects of the test pesticides on both spleen and liver.

\section{Time-course pattern for brain AChE activity}

Analysis revealed that there were significant inhibitions of brain AChE among fish exposed to BPMC $(K W=14.02, P<0.05)$. Figure 3 shows the pattern of brain AChE inhibition. The peak of brain AChE inhibition was observed on the 14-dayexposed fish which was $40.7 \%$ inhibition rate. The AChE inhibition on the 21 
- and 28-day-exposed fish was lower compared to the 14-day-exposed fish. Liwag et al (2009) observed the same trend in which AChE activity of $O$. niloticus exposed to carbaryl and chlorpyrifos insecticides, which are both cholinesterase inhibitors, improved after longer exposure to the constant concentration level of the insecticides. Morgan et al (1990) explained that recovery of AChE activity was a function of the degree of initial inhibition. It was explained that recovery was a result of de novo synthesis of the enzyme protein. This suggests that the concentration used in the present study was quite low and that the initial inhibition was not great, thereby enabling the fish to recuperate to the continued exposure.

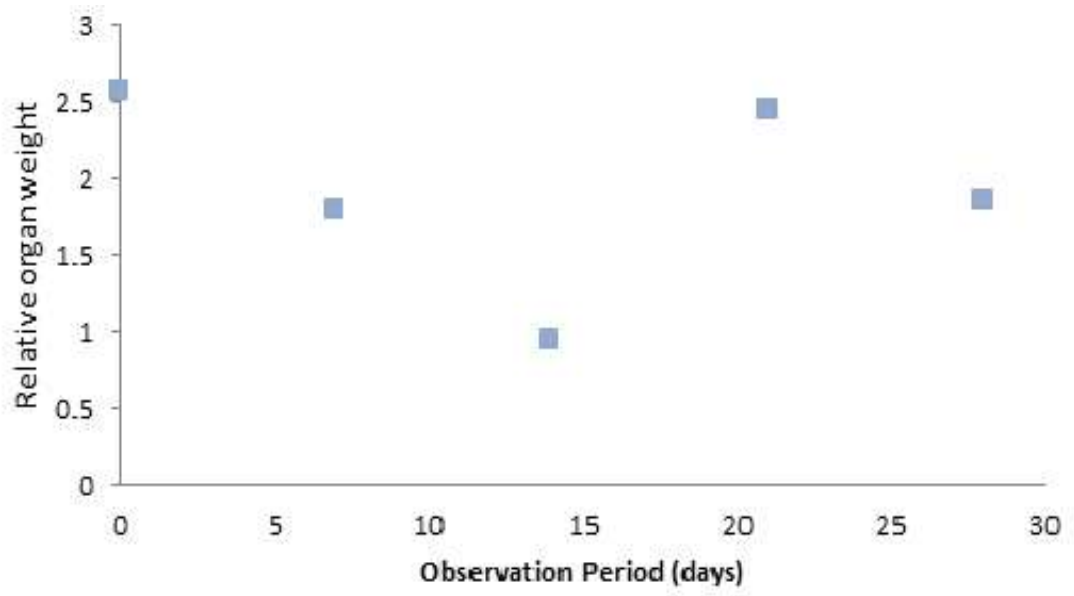

Figure 2. Relative liver weight of Oreochromis niloticus juveniles at different length of exposure to constant dose of BPMC $(0.08 \mathrm{mg} / \mathrm{L})$. $\mathrm{N}=10$ fishes per group. $(\mathrm{KW}=14.02$, $P<0.05)$

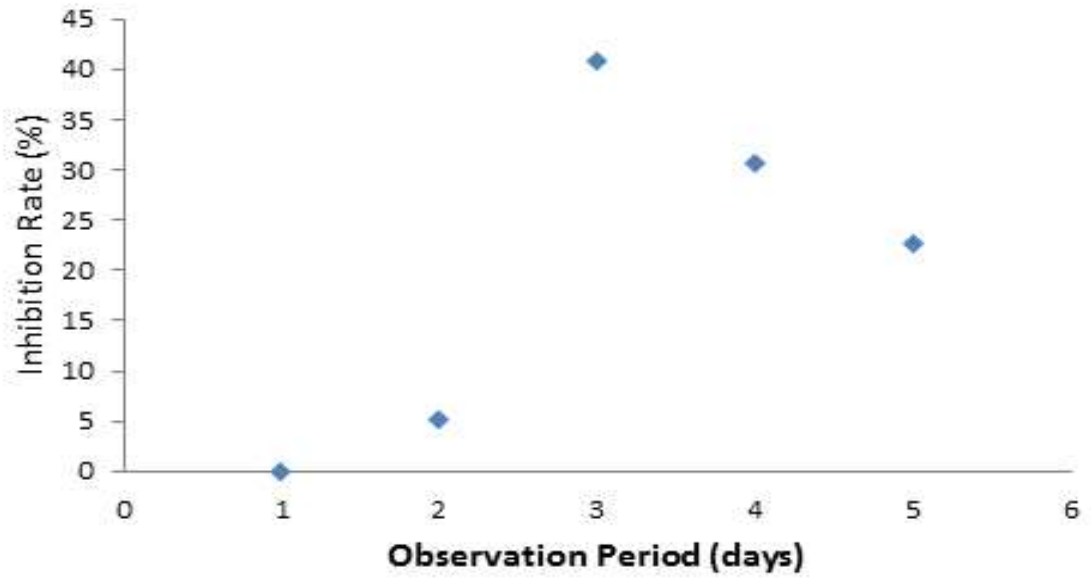

Figure 3. Inhibition rate of brain acetylcholine (AChE) activity in Oreochromis niloticus juveniles at different length of exposure to constant dose of BPMC $(0.08 \mathrm{mg} / \mathrm{L}) . \mathrm{N}=10$ fishes per group. $(K W=14.02, P<0.05)$ 
Acetylcholinesterase Activity in Nile Tilapia

Time-course pattern for muscle AChE activity

Muscle AChE activity was also significantly inhibited by the exposure to BPMC $(K W=6.87, P<0.05)$. The highest inhibition rate observed was on the 21-dayexposed fish (Figure 4). John and Prakash (2003) observed that cholinesterase inhibitors accumulate more in muscle than other tissues and explained that it may be due to their direct contact to the insecticides. The direct exposure of muscle tissues to the test compound could also explain why muscle tissues recuperated late compared to brain tissues.

The brain is the most sensitive and appropriate tissue to be analyzed for AChE activity. de Almeida et al (2005) explained that the degree of tissue enervation is related to the amount of AChE. Meaning, the higher the AChE concentration, the higher the inhibition susceptibility is.

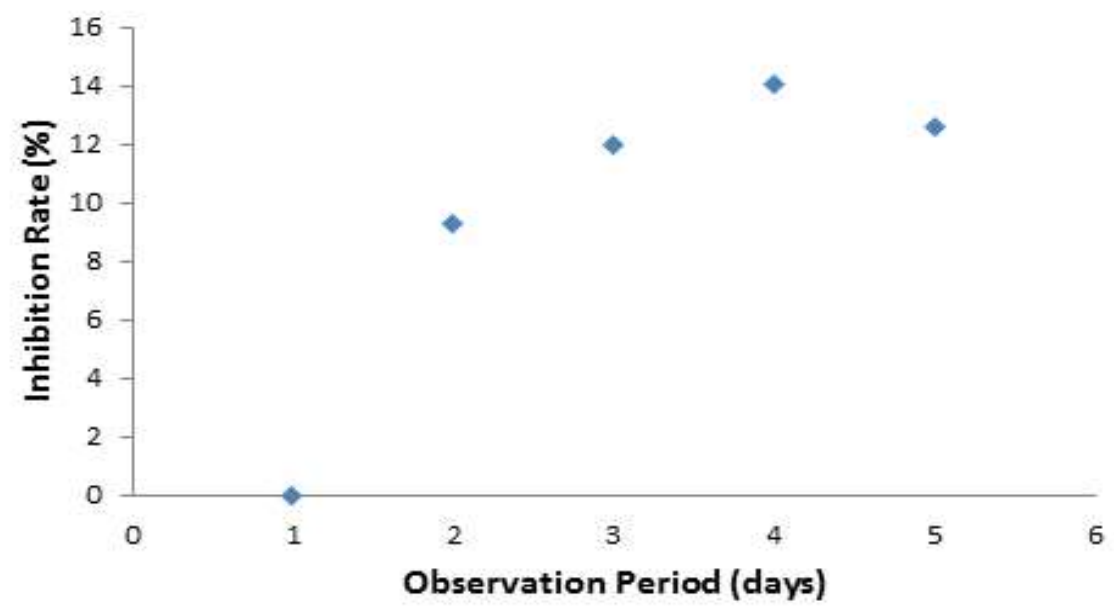

Figure 4. Inhibition rate of muscle acetylcholine (AChE) activity in Oreochromis niloticus juveniles at different length of exposure to constant dose of BPMC (0.08 $\mathrm{mg} / \mathrm{L}) . \mathrm{N}=10$ fishes per group. $(\mathrm{KW}=6.87, \mathrm{P}<0.05)$

\section{CONCLUSION}

Fish exposed to the residual concentrations of BPMC did not show any overt treatment-related symptoms of poisoning. There was a significant influence of test insecticide on the relative weights of the liver and it is generally lower than that of the control fish. These could have been a direct effect of the pesticide or an adaptive process to cope with constant exposure to the toxicant.

AChE inhibitions were found to be significantly different among control and treated groups. BPMC-exposed fish had the highest enzyme brain AChE inhibition rate of $40.7 \%$ on the $14^{\text {th }}$ day of exposure and lower in the 21 - and 28 -day exposed fish. The same pattern was also observed in muscle AChE inhibition wherein inhibition rate decreased as exposure continued. 
This study shows that Nile tilapia is sensitive enough to be affected by environmentally detected levels of the insecticide BPMC. Effects on relative organ weights, as well as the brain and muscle AChE activity, were observed. The apparent decrease of AChE inhibition rate could provide insights as to how frequent should sampling of fishes be in the wild if Nile tilapia will be used as biomarkers for carbamate exposure. It is suggested to add parameters such as histological examination to further strengthen the potential of Nile tilapia as a bioindicator to monitor the impact of carbamate insecticides.

\section{ACKNOWLEDGMENT}

The author would like to thank the people at the UPLB Limnological Research Station for the assistance, most especially to Dr. Pablo P. Ocampo who was the Head of the research station and the professor for Zoology 299 (Special Problem). The author dedicates this work to Dr. Ocampo who passed away in 2015. Finally, the author would like to express his gratefulness to DOST-ASTHRDP for the financial support.

Disclaimer: The use of trade names in this study does not imply endorsement or criticism of the mentioned products.

\section{REFERENCES}

Aragon MR. 2000. Subchronic toxicity effects of the residual levels of chlorpyrifos on cytochrome $\mathrm{P}_{450}$ induction, selected hematological and histological parameters of Nile tilapia (Oreochromis niloticus Linn., MS thesis), University of the Philippines at Los Baños, Philippines.

Bajet CM, Kumarb A, Calingaciona MN \& Narvacana TC. 2012. Toxicological assessment of pesticides used in the Pagsanjan-Lumban catchment to selected non-target aquatic organisms in Laguna Lake, Philippines. Agricultural Water Management. 106: 42- 49.

Beauvais SL, Cole KJ, Atchison GJ \& Coffey M. 2002. Factors affecting brain cholinesterase activity in Bluegill (Lepomis macrochirus). Water, Air, and Soil Pollution 135:249-264.

Bose S, Nath S \& Sahana SS. 2011. Toxic impact of thiamethoxam on the growth performance and liver protein concentration of a freshwater fish Oreochromis niloticus (trewavas). Indian Journal of Fundamental and Applied Life Sciences. 1 (4): 274-280.

Calumpang SMF, Medina MJB, Tejada AW \& Medina JR. 1997. Toxicity of chlorpyrifos, fenubucarb, monocrotophos, and methyl parathion to fish and frog after a stimulated overflow of paddy water. Bulletin of Environmental Contamination Toxicology, 58:909-9014.

Chung MK, Kim JC \& Han SS. 2002. Developmental toxicity of flupyrazofos, a new organophosphate insecticide, in rats. Food and Chemical Toxicology, 40: 723729.

Coppage DL \& Bradeich E. 1976. River pollution by anti-cholinesterase agent. Water Research, 10:19-24. 
Acetylcholinesterase Activity in Nile Tilapia

De Almeida1 LC, Aguiar LH \& Moraes G. 2005. Effect of methyl parathion on the muscle and brain acetylcholinesterase activity of matrinxã (Brycon cephalus). Ciência Rural. 35 (6): 1412-1416.

De Silva CD \& Ranasinghe J. 1989. Toxicity of four commonly used agrochemicals on Oreochromis niloticus (L.) Fry. Asian Fisheries Science. 2:135-145.

Ellman GL, Courtney KD, Andres V \& Featherstone RM. 1961. A new and rapid colorimetric determination of acetylcholinesterase activity. Biochemical Pharmacology, 7: 88-95.

Evans JJ, Pasnik DJ, Horley P, Kraeer K \& Klesius PH. 2008. Aggression and mortality among Nilr tilaipia (Oreochromis niloticus) maintained in the laboratory at different densities. Research Journal of Animal Sciences. 2(2): 57-64.

John PJ \& Prakash A. 2003. Bioaccumulation of pesticide on some organs of freshwater catfish Mystus vittatus. Bulletin Environmental Contamination and Toxicology, 70: 1013-1016.

Gawish AM, Issa AM, Ali MA \& Ismail GA. 2011. Histopathological, histochemical and biochemical studies on the effects of lorsban on the liver of nile tilapia and the possible declaring effect of antioxidants. Australian Journal of Basic and Applied Sciences, 5(12): 75-94

Gruber SJ \& Munn MD. 1998. Organophosphate and carbamate insecticides in agricultural waters and cholinesterase inhibition in common carp (Cyprinus carpio). Archives of Environmental Contamination and Toxicology, 35:391-396

Liwag AG, Ocampo PP \& Ubaldo NN. 2009. Effects of acetylcholinesteraseinhibiting chemicals on Nile tilapia (Oreochromis niloticus Linn) at pre- and post-hatching stages of development. Philippine Entomology, 23(2):155- 173.

Marco M-P \& Barceló D. 1996. Environmental applications of analytical biosensors. Measuring Science Technology, 7:1547-1562.

Monteiro DA, Almeida JA, Rantin FT \& Kalinin AL. 2006. Oxidative stress biomarkers in the freshwater characid fish, Brycon cephalus, exposed to organophosphorus insecticide Folisuper 600 (methyl parathion). Comparative Biochemistry Physiology, 143:141-149.

Morgan MJ, Fancey LL \& Kiceniuk JW. 1990. Response and recovery of brain AChE activity in Atlantic salmon exposed to fenitrothion. Canadian Journal of Fisheries and Aquatic Sciences, 47:1652-1654

Payne JF, Mathieu A, Melvin W \& Fancey LL. 1996. Acetylcholinesterase, an old biomarker with a new future? field trials in association with two urban rivers and a paper mill in Newfoundland. Marine Pollution Bulletin, 32(2):225-223.

Que Hee SS. 1993. Biological monitoring: An introduction (p672). Van Nostrand Reinhold, USA.

Rondon RB. 2005. Trends in pesticide in major crops. Paper presented the 2005 Pest Management Council of the Philippines Conference, PhilRice, Muñoz, Nueva Ecija, Philippines.

Singh NN, Das VK \& Singh S. 1996. Effect of Aldrin on carbohydrate, protein and ionic metabolism of a fresh water catfish Heterthiamethoxamneustes fossilis. Bulletin of Environmental Contamination and Toxicology, 57:204-210.

Tõugu V. 2001. Acetylcholinesterase: mechanism of catalysis and inhibition. Curr Med Chem - Cent Nerv Syst Agents, 1:155-170. 
Tripathi PK, Srivastava VK \& Singh A. 2003.Toxic effects of dimethoate (Thiamethoxam) on metabolism and enzyme system of freshwater Teleost Fish (Channa punctatus). Asian Fisheries Science, 16:349-359.

Varca ML. 2012. Pesticide residues in surface waters of Pagsan-Lumban catchment of Laguna de Bay, Philippines. Agricultural Water Management. $10635-41$

Varo I, Serrano S, Pitarch E, Amat F, Lopez FJ \& Navarro JC. 2000. Toxicity and bioconcentration of Chlorpyrifos in Aquatic Organisms: Artemia parthenogenetica (Crustacea), Gambusia affinis; and Aphanius iberus (Pisces). Bulletin of Environmental Contamination and Toxicology, 65:623630.

Venkateswara Rao J. 2004. Effects of monocrotophos and its analogs in acetylcholinesterase activity's inhibition and its pattern of recovery on euryhaline fish, Oreochromis mossambicus. Ecotoxicology and Environmental Safety, 59:217-222.

Watson WP \& Mutti A. 2004. Role of biomarkers in monitoring exposures to chemicals: present position, future prospects. Biomarkers, 9(1): 21 1-242.

Wijesuriya DC \& Rechnitz GA. 1993. Biosensors based on plant and animal tissues. Biosensors and Bioelectronics, 8(3-4):155-160. 